\title{
DEMOCRATIZATION OF INTERNATIONAL RELATIONS AND ITS IMPLICATIONS FOR DEVELOPMENT AND APPLICATION OF INTERNATIONAL LAW*
}

\author{
M.C.W. Pinto**
}

The purpose of this paper is to explore whether 'democracy', a form of governance which evolved within a community of human beings, may be applied in the quite different context of a collectivity of states. In so doing, I shall refer to the context in which the call for 'democratization of international relations' has been presented; mention the elements of principle, which, I think, combined at a particular time in the post-colonial period to inspire this trend; explore the extent to which some aspects of democracy have, in fact, been transposed from the human level to that of the collectivity of States, with implications for treaty-making under the auspices of the United Nations, and for the functioning of international institutions; and suggest some areas in which the process of democratization, with limited goals, may continue in future.

\section{THE CALL FOR 'DEMOCRATIZATION OF INTERNATIONAL RELATIONS'}

For most of us, the term 'democracy' brings to mind the counting of votes, the aggregation of preferences for the purpose of deciding an issue, or election to public office, by sheer weight of numbers. It means the right of all persons of a prescribed age of maturity who are not affected by some disability prescribed by law, to participate in that decision or election. Of course, democracy does imply that the votes of a majority will prevail, but it also

\footnotetext{
* Revised version of a paper presented at the United Nations Congress on Public International Law, held within the framework of the United Nations Decade of International Law, New York, March 1995.

"* Attorney of the Supreme Court of Sri Lanka; of the Inner Temple barrister-at-law; General Editor.
} 
means a great deal more: it means, for example, the fair representation of interests in a legislative assembly; it means that in a representative democracy the people retain power over decisions that affect them through holding regular elections to representative office; it means constitutional protection of minority positions; and it means a separation of governmental functions to provide 'checks and balances', ultimate authority being vested in an independent judiciary with power to determine whether governmental action accords with the constitution or fundamental law. ${ }^{1}$

But it was a vision of democracy as the triumph of numbers - of the views, and thus the projects of the great majority of the world's peoples - that inspired the developing countries and the Non-aligned to call for the 'democratization of international relations', and continues to do so today. Thus, at the first meeting of the United Nations Conference on Trade and Development (UNCTAD) in 1964, the Group of 77 insisted that the UNCTAD Board take decisions by a two-thirds majority, since they attached "cardinal importance to democratic procedures which afford no position of privilege in the economic and financial, no less than in the political spheres". 'Democratization of international relations' has been a stated goal of the Non-aligned Movement at least from the time of its Lusaka meeting in $1970,{ }^{2}$ and was re-iterated forcefully in its Jakarta message in September $1992 .{ }^{3}$ The idea that democracy should prevail "within the family of nations" received endorsement from the Secretary-General of the United Nations in his Agenda for Peace in 1993, ${ }^{4}$ while "expanding democracy in relations among States and at all levels of the

\footnotetext{
${ }^{1}$ The following passage from a work by CHARLES BEITZ captures admirably the essence of the democratic process:

“. . . the central virtue of democratic forms is that, in the presence of a suitable social background, they provide the most reliable means of reaching substantively just political outcomes consistently with the public recognition of the equal worth or status of each citizen. Democratic forms succeed in achieving this aim . . . less because they aggregate existing preferences efficiently than because they foster a process of public reflection in which citizens can form political views in full awareness of the grounds as well as the content of the [possibly competing] concerns of others . . . we must understand [democracy] as a deliberative mechanism that frames the formation and revision of individual political judgments in a way likely to elicit outcomes that treat everyone's interests equitably". Political Equality: an Essay in Democratic Theory (Princeton University Press, 1989) 113.

For a survey of aspects of the attractiveness and viability of modern democracy, see Professor DuNN's masterly concluding essay in JoHN DUNN (ed.), Democracy, the unfinished journey 508 B.C. to A.D. 1993 (Oxford University Press, 1993) 239 et seq.

2 "The democratization of international relations is therefore an imperative necessity of our times." (paragraph 7)

${ }^{3}$ Paragraph 5.

${ }^{4}$ Paragraphs 19, 82.
} 
international system" is suggested as an aspect of a fifth "dimension of development" in the Secretary-General's Agenda for Development issued in $1994 .^{5}$

It is important to bear in mind that democracy evolved as a form of governance among natural persons, human beings within a discrete legal and political unit. We may search in vain for any suggestion that 'democracy' prevailed or should be adopted as the constitutive principle in the world of states before the decade of the 1960s, in retrospect, the decade of decolonization. The term is not used in such a context - or, for that matter, in any context in the Charter of the United Nations nor the Statute of the International Court of Justice, nor until recently was it used in the constituent instrument of an international organization, or, for that matter, in any multilateral convention. No treaty seeks to secure for states the equivalent of the right of the citizen described in Article 25 of the International Covenant on Civil and Political Rights. It would thus seem impossible to derive the prevalence of an 'interstate' democracy from the early practice of states.

\section{ORIGINS IN PRINCIPLE}

However, four elements of such a concept did exist unsynthesized at the inter-state level. Thus, the doctrine of sovereignty, developed among European thinkers from the fifteenth century on, would eventually strengthen units of the Holy Roman Empire in the exercise of their rights, recognized by the treaty of Westphalia, to form alliances with 'foreign' powers, or to make war. A second doctrine, that of the equality of states, had its roots in Christian theology. It held that, as human beings were equal before God, and were entitled to be treated as equal, so, by analogy, were states. ${ }^{6}$ Apparently resting

\footnotetext{
${ }^{5}$ Paragraphs 116-136, esp. paragraph 131.

6 "Since men are naturally equal, and a perfect quality prevails in their rights and obligations, . . . Nations composed of men . . . are naturally equal, and inherit from nature the same obligations and rights. Power or weakness does not in this respect produce any difference. A dwarf is as much a man as a giant; a small republic is no less a sovereign state than the most powerful kingdom."

VATTEL, The Law of Nations (trans. Joseph Chitty, London, 1834) paragraph 18 . The Declaration on the New International Economic Order (1974) recalls the Charter principle of the 'sovereign equality of States' and urges:

"Full and effective participation on the basis of equality of all countries in the solving of world economic problems in the common interest of all countries."

Given the perceived levelling potential of the 'oil weapon', the step from juridical equality to participatory equality seemed a short one. A sister resolution adopted by the General Assembly
} 
on metaphysical foundations, it generated what might be called an 'anthropomorphic' view of the state - the state in the image of man. By the middle of the nineteenth century the doctrine had gained such currency that Chief Justice MARSHALL could declare:

"No principle of general law is more universally acknowledged than the perfect equality of nations. Russia and Geneva have equal rights."7

The doctrines of sovereignty and of "the equality of . . . nations large and small" - later to be mentioned separately or run together in the Charter of the United Nations, which also refers to "the sovereign equality of all its members" - were not sufficient, however, to generate the idea of transposing democracy to the inter-state level. Notions of sovereignty and equality in 1815 gave no state the right to attend the Congress of Vienna, nor did any State enjoy such a right of representation, much less of participation, at any of the great, essentially European conferences of the nineteenth century. Attendance then, was by invitation only; and whether an invited state would be asked for its views, or merely requested to ratify a decision, was a matter determined by a dominant group of 'Great Powers'. ${ }^{8}$ Although the unanimous consent of all states was required for the adoption of a proposal, the intent and effect of the

in the same year, the Charter of Economic Rights and Duties of States (1974) declared:

"All States are juridically equal and, as equal members of the international community, have the right to participate fully and effectively in the international decision-making process . . .."

On the relationship between 'equality' and 'participation' in this context, see the 'Analytical Study' by UNITAR, annexed (Annex III) to a Report of the UN Secretary-General entitled "Progressive development of the principles and norms of international law relating to the New International Economic Order" (A/39/504/Add.1), which observes:

"There are two aspects to the question of participation: access, or taking part in the process of decision-making, and weight or the actual part taken in this process . . . Obviously, equality applies to access. But neither instrument [Declaration on the NIEO, Charter of Economic Rights and Duties of States] specifies the modalities of 'full and effective participation', i.e. whether it necessarily implies 'equal participation' in the sense of equal weight in the decisionmaking process." (paragraphs 107-8)

${ }^{7}$ The Antelope, 10 Wheaton (US Sup. Ct.) Reports 66, 122.

${ }^{8}$ As one commentator has observed:

“. . . the Congress of Vienna as a Congress of all Europe was never constituted. It remained a Congress of the Great Powers, who for their convenience had summoned the smaller Powers of Europe to meet them. The idea of a constituent assembly, imagined by some, . . . was found to be impossible. The large number of small States made such an assembly impracticable in any case. But the wishes of the masters of Europe were from the first clear and unbending on this point. They considered themselves as 'Europe', and at the Congress they asserted successfully the ascendancy of the Great Powers. The smaller States were only to be admitted at such times and on such terms as suited those who had great resources and armies at their command."

C.K. WEBSTER, The Congress of Vienna 1814-1815 (Oxford University Press, 1919) 77. 
rule was to enable a small minority of Great Powers to protect their interests. The dissent of a small State then, as now, was of little consequence. ${ }^{9}$ Democracy in its modern form had first to be adopted more widely within each state before thought of its application to the collectivity of states could emerge. Moreover, the number of recognized States was relatively small, and interacted according to a strict hierarchy, notwithstanding formal acknowledgement of a principle of equality.

So it was that the effects of another principle had to be felt before the demand for democratization of international relations could gather momentum: the principle of equal rights and self-determination of peoples. Elevated from the political to the legal plane not without controversy, and gathering support inspired by President WILSON's Fourteen Points, ${ }^{10}$ this principle too found a place in the Charter of the United Nations. Under its influence the world's 'population' of States swelled to unimagined proportions.

But the doctrines of sovereignty and equality, acting upon the large number of states emerging in the decades following World War II in the era of decolonization could still not provide the critical mass of principle needed to generate the demand for democracy in international relations. The final additive was the principle of distributive justice that inspired those emerging countries. In it were subsumed such ideas as the general duty of states to cooperate to 'correct inequalities and redress existing injustices', and 'preferential and non-reciprocal treatment for developing countries'. Many of the so-called new states had been led to independence by politicians who had absorbed Marxist philosophy in the universities of colonial capitals. Active in the international arena, they called for compensation for the exploitation of their countries by the former imperial powers. Their vision of a future world order could be expressed succinctly through one of the central tenets of Marxism which also carried substantial moral, if not religious authority: from each according to his ability, to each according to his needs. ${ }^{11}$

\footnotetext{
${ }^{9}$ As one authority puts it, "Unanimity was possible only by the majority giving way to the minority". JAMES LORIMER, The Institutes of the Law of Nations, Vol. 1 (London, 1883) 47.

${ }^{10}$ LENIN too, advocated the principle of self-determination for quite different reasons.

${ }^{11}$ Although it is impossible to assess the scope of the impact of this epigram from MARX's Critique of the Gotha Programme, there can be little doubt that it produced a resonance in the minds of intellectuals around the world. For MARX, true communism was incompatible with any form of exchange, and what distinguished communist society from others attempting redistribution of wealth, goods and power, was the complete disappearance of exchange-value that would occur in the final stages of communism when the state itself would have no function and 'wither away'. The epigram has affinities with the basic tenets of all of the world's religions, and exercised a similar mass appeal notwithstanding its utopian character, particularly in countries subject to colonial rule or other exploitative regimes.
} 


\section{DEMOCRACY AND THE COLLECTIVITY OF STATES}

When the representatives of states call for the 'democratization of international relations', they are likely to do so influenced by what we might call the 'anthropomorphic' view that the state is a person in a community composed of other such 'state-persons'. On that view, such state-persons are the repositories of 'democratic' rights and duties, rather than the natural persons (the true demos) of which the state-persons are composed. The method of choice for the systematic codification of international law today is the plenipotentiary conference of these 'state-persons'. Such a conference, at which legal rules will be proposed, deliberated, and adopted or rejected, does bear a superficial resemblance to a national legislature. Most often convened today under the auspices of the United Nations, the conference is likely to have before it as a basic text draft articles formulated by a broadly representative group of agreed composition, the International Law Commission, for example, or an intergovernmental negotiating committee. What in Vienna in 1815 might have been the privilege of being represented at the invitation of a Great Power, and of approving some predetermined result, has evolved at least since the Vienna Declaration on Universal Participation (1969), into a full right of participation by every state-person in the 'legislative' process, subsuming the right to be represented, to have access to information, to be heard on the issues, and to cast a vote equal in weight or value with the vote of every other State-person, and have the views of the majority prevail (one-state-one-vote/majority rule OSOV/M).

The modern 'legislative' conference has other 'democratic' features aimed at ensuring that proposals are discussed fairly and openly, that every effort is made to reach consensus, and, when a decision must be taken by a vote, that procedural and substantive rules agreed to in advance will determine the outcome. In general, votes on procedural issues are to be decided by a simple majority, while votes on substantive issues might be decided by unanimity, consensus or prescribed majorities depending upon the level of their importance. At least since the 1969 Law of Treaties Convention (Article 9), a majority of $2 / 3$ of those present and voting would be required unless, by the same majority a different rule were to be adopted. All such rules are aimed, in general, at safeguarding minority positions. Protection of minority positions 
is also the purpose of providing for 'cooling-off' periods to be used for consultations aimed at reconciling conflicting views. ${ }^{12}$

While the foregoing procedural features of a modern treaty-making conference may to some extent mirror those of a national legislature in their democratic flavour, the resemblance is superficial, and many other features of the international legislative process find no domestic parallel. To begin with, the representatives in a national legislature are elected directly by the people (the true demos) or by the people through a system of intermediate steps known and accepted by them in advance. By contrast, the representative of a state at a plenipotentiary conference will have been appointed by some organ of a state (a minister or a president). The connection between conference representative and people could well be remote, if it were to exist at all, notwithstanding the elected status of the appointing authority. Moreover, the legislative process lacks a system: there is no regular assembly, and no legislative programme, except possibly the work schedule of the International Law Commission, and the Sixth Committee's annual observations on priorities. Conferences are convened at the initiative of one or more states motivated essentially by their own policy imperatives.

Within a democracy of natural persons the votes of the majority are likely to be decisive as to the enactment of a law, and the organized forces of the state acting in accordance with the law of the land will begin to supplement traditional social control in securing immediate compliance with it. At a plenipotentiary conference, the votes of representatives, in effect, bind only the conference, as the initial step in the lengthy process of deliberation required before it could become binding on participating states. A collectivity of

\footnotetext{
${ }^{12}$ See generally the Rules of Procedure of the Third United Nations Conference on the Law of the Sea (UNCLOS), A/CONF.62/30/Rev.3 (1974) Chapter VI; and of the United Nations Conference on Environment and Development (UNCED) A/CONF.151/2 (1992) Chapter VII. The decision-making bodies of international organizations adopt similar procedures. See for example article 161, paragraph 8 of the UN Convention on the Law of the Sea, on the Council of the International Seabed Authority; and Article 7 of the UN Framework Convention on Climate Change on the Conference of the Parties. Compare Articles 15 and 16 of the latter concerning amendment of the Convention and its annexes.

As the UNITAR 'Analytical Study' referred to (note 6 above) concedes: "It cannot be gainsaid . . . that the spirit of the majority system, especially on the international level and between sovereign States, is against the complete disregard of the right of the minority or its exclusion from the process of decision-making altogether as if it did not exist. The spirit of the majority system rather favours the debating of issues of common interest and trying to find generally acceptable solutions and different ways and means of accommodating the interests of all the segments present, so that the majority votes for 'railroading' or imposing a decision are only used as a last resort when a deadlock is reached and there is no other way of breaking it" (paragraph 14).
} 
sovereign and equal state-persons, of widely disparate capabilities and levels of political influence and lacking an effective over-arching 'law of the land', offers a context infinitely more tolerant of arbitrary behaviour than does the collectivity of natural persons. For the efficient implementation of treaties the resources of the powerful - always a very small minority - are often essential. Safeguards for minority positions at the legislative stage become of critical importance, and the weight of majorities less significant. Minority safeguards in treaty-making - permission to 'opt out' of certain obligations, to make reservations, to withdraw from a treaty and, above all, to remain outside the ambit of a treaty by refraining from ratifying or approving it - these recognized liberties of state-persons, are not among the attributes of natural persons within a democratically organized society, who are at all times subject to the law of the land and have little scope for avoiding or modifying their legal obligations unilaterally.

Thus, while the democratic OSOV/M rule now appears entrenched as a constitutive principle of the international legislative process, minority safeguards ensure that its effects are not felt beyond the conference stage, and there is little that would compel compliance with the outcome - the text of the treaty adopted by the conference - unless and until specific democratically motivated procedures are voluntarily undertaken at the national legislative level. And here we may note two apparent contradictions in connection with democratization, viewed in relation to the treaty-making aspect of international relations: (1) the principle of sovereign equality, which was a powerful factor in winning for all states the democratic right to participate in treaty-making, is also the basis of the right of every state to reject the very treaty it may have helped to formulate; and (2) while democratic forms, observed at the interstate level may produce a treaty text acceptable to the generality of states, democracy operating at the national level may result in rejection of the treaty by individual states whose participation in the treaty is of critical significance to its successful implementation. The importance of these observations is that they highlight an area upon which efforts at democratization of international relations might usefully be focussed: effective articulation of democracy at the inter-state level, with democracy at the national level.

These contradictions are of particular relevance in connection with the efficacy of treaties which, concluded in accordance with 'democratic' procedures, nevertheless establish organizations in which some Member States are accorded preferential rights. These organizations have in common that they are charged at least in part, with managing the transfer of resources from a small minority of affluent industrialized countries (perhaps 10 in a state-person 'population' of 185 , or less than $5 \%$ ), for what may be called 'community 
purposes', primarily (1) the maintenance of international peace and security, and (2) raising the living-standards of the poor countries. Thus, organs like the Security Council of the United Nations and the Executive Directors of the World Bank and the International Monetary Fund must adopt decisions with regard to resource transfers that are to take effect immediately, or without renewal or confirmation of consent in each case by the transferors' national legislatures. Accordingly, the parent treaty in each case provides the transferor's representatives with safeguards: representation is assured on decisionmaking bodies of limited composition, otherwise re-constituted through periodic elections; and they are granted preferential voting rights such as the right to forbid or veto a decision, and voting strength according to level of contribution. To the transferor state, its national resources - whether in the form of funds, technology, expertise or units of its armed forces - are assets as much under its permanent sovereignty as its natural resources. If substantial transfers are to occur without recourse to the national legislature - we might refer to them as 'automatic transfers' - the latter would require as a condition of the state's joining the treaty, that its minority position be granted appropriate constitutional safeguards. To those state-persons whose resources are to be so transferred, democracy at both national and inter-state levels seem to require provision for such constitutional safeguards. To the potential recipients of resources, however, such measures, by suspending the operation of the OSOV/M rule, appear to distort, if not to pervert democratic forms, and, moreover, to reflect and perpetuate the inequality of states, rather than their equality.

On the other hand, the texts which created organs like the Security Council of the United Nations or the Executive Directors of the World Bank and the International Monetary Fund were adopted at conferences which by contemporary standards were based on universal participation and the OSOV/M rule, so that their 'democratic' origins could scarcely be questioned. There can be little doubt that, at such conferences, and in the subsequent ratification or accession procedures, the representatives of the majority, the less developed countries, made a choice, viz. that, in the circumstances, co-operation whereby some aspects of 'equality' might appear to be sacrificed, was preferable to no cooperation at all. Nor would it appear that such a choice is inconsistent with the freedom that characterizes democracy. For example, last year, an overwhelming number of States voted to convert the voting system of an organ created by treaty - the Council of the International Sea-bed Authority - from one based on equality, to one that conferred preferential voting rights on some industrialized countries. This safeguard was offered so that national democracies of the latter, which had hitherto exercised their right to remain outside the treaty, would then be persuaded to join. Once again the prospect that the 
industrialized countries might withhold valued support was sufficient to persuade the majority to accord them the minority safeguards requested. If this interaction was inconsistent with democratic principles, it certainly did not appear from the tone or content of statements welcoming the amendment which was adopted.

In what may be the first treaty ever to prescribe, in terms, the application of 'democracy' in inter-state relations, the 1992 Rio Convention on Biological Diversity requires that the financial mechanism foreseen in Article 21 "shall operate within a democratic and transparent system of governance". A sister Convention on Climate Change, perhaps less ambitious, provides that its financial mechanism "shall have an equitable and balanced representation of all Parties within a transparent system of governance". ${ }^{13}$ The constitution of the Biodiversity Convention's financial mechanism would be the first attempt to produce an authentic interpretation of what democracy means in its application to inter-state relations.

\section{EXPANSION OF DEMOCRATIZATION}

It is evident then, that many aspects of the participatory element of democracy have already been transposed from the human to the state level. Fundamental differences between a society or community of human beings, and the collectivity of states make it extremely unlikely that an important feature of that system - OSOV/M - could ever be comprehensively applied among states. However, there are other areas in which the process of democratizing international relations could make substantial progress. The broad objective of such efforts should be to allow the wishes of the human community - the true demos - behind the apparatus of the state more effectively to influence decision-making at the international level.

To that end, the current practice among many states whereby the effective leadership of a delegation to a treaty-making conference is left to appointed ${ }^{14}$

${ }^{13}$ UN Framework Convention on Climate Change, Article 11, paragraph 2, and Article 21, paragraph 3.

${ }^{14}$ LORIMER long ago observed: “. . . the leading objection to treaties as a source of the law of nations, as well as the chief cause of their untrustworthiness as separate transactions, consists in the necessity which exists, or is supposed to exist, for their being negotiated and even ratified by the executive independently of the legislative factor in national affairs, and the consequent risk of their failing to represent the national will . . . the international effect of this supposed necessity, is to reduce treaties negotiated by constitutional States very nearly to the level of those negotiated by despotic States". LORIMER, op. cit. n.9, pp. 42-3. 
diplomatic or technically qualified persons, rather than the elected representatives of the people, should be examined. Consideration should be given to early and comprehensive (rather than merely formal) involvement in the treatymaking process of members of the national legislature familiar with the subject-matter of the treaty, reflecting where possible a multi-party approach. We may even look to a time when treaty-making might have become so institutionalized that a state would hold special elections to determine who should represent the demos at a conference. Of particular importance would be the routine inclusion in treaty-making procedures, of formal commitment by states concerning timely national consideration and action upon treaty texts that have been adopted, coupled with institutional monitoring and reporting requirements regarding action or lack of action on the matter ${ }^{15}$. Such measures could promote the better articulation, now needed, between democracy at the interstate level and democracy at the level of the national legislature.

With the aim of reaching the people - the true demos - and mobilizing opinion, democratic features related to the availability of information should be maintained. This would apply to all fora where decisions are to be taken, such as treaty-making conferences or the work of established organs, but would be of special relevance to the work of organs of limited membership. Such democratic features would include 'transparency', 'openness', and 'accountability', given effect to inter alia through the availability of records of debates in as much detail, and in as timely a manner as possible, subject to the demands of economy. Video-conferencing facilities and interpretation services have developed to an extent that makes it feasible to hold at least some phases of multilingual conferences without the expense and other resource-related inconveniences of overseas travel.

The aim of presenting the sense of public opinion as distinct from governmental policy on issues could also be served by incorporating into the treatymaking process at both the national and international level, procedures for consulting non-state entities, in particular, legal persons such as commercial corporations, as well as other bodies generally referred to as 'non-governmental organizations'.

'Regional representation' or representation on a geographical basis, incorporated in the UN Charter itself as an article of faith, should be reconsidered in the light of some inherent weaknesses, and, to the extent possible, refined. The extent of differentiation of constituencies to be represented, such

${ }^{15}$ Distinguished precedents exist: see the procedures for dealing with Conventions adopted by the International Labour Conference, Constitution of the International Labour Organisation, Articles $19,22,30$. 
as sub-regions, which now varies greatly depending on the region, should be generalized. Greater differentiation of constituencies would also make more effective the prevailing practice of 'rotation' of representative capacity. If, on the other hand, some states were to find representation on a regional basis less than satisfactory, representation of a group that crosses geographical lines should be recognized.

Permanent membership and preferential voting rights conferred on representatives in organs charged with managing the 'automatic transfer' of resources from their states, are now among the safeguards of minority positions inherent in democracy as it prevails among state-persons. Additional categories of criteria for permanent membership may need to be recognized, such as size of population and size or future potential of an economy. Where effective regional integration exists among states at the national level, as within the European Union, the basis on which permanent membership of the group as such could be admitted should be studied, with a view to its more generalized application. Expansion of permanent membership and, where appropriate, conferment of preferential voting rights should, however, be balanced by a proportionate increase in the numbers of non-permanent or periodically elected members, to maintain undiminished the scope and variety of participation in the work of the organ concerned.

\section{AN INDEPENDENT JUDICIARY}

One of the major achievements of the international community in the twentieth century, and a landmark in progress toward democratization of international relations, has been the establishment by treaty of the Permanent Court of International Justice (PCIJ) and its successor, the International Court of Justice. Although the International Court of Justice is an integral part of the United Nations, and its budget within the control of the General Assembly (Statute, Articles 32, 33), the Court is conceived along the lines of an independent judiciary in a democratic system of governance: many provisions of Charter and Statute seek to make the Court 'separate' in the exercise of its powers, and not subject to control by the electors who place the judges in office - the representatives of the State-persons members of the General Assembly and the Security Council. Moreover, the seat of the Court is The Hague, physically removed from the headquarters of its parent institution, New York, and its politically charged atmosphere.

Neither the Charter nor the Statute of the Court expressly contemplate procedures for the purpose of having the Court declare whether or not the actions 
of an organ of the United Nations are in conformity with the Charter. ${ }^{16}$ On the other hand, its position as the "principal judicial organ of the United Nations" (Article 92 of the Charter); its general jurisdiction under Article 36 (1) of its Statute to deal with "all cases which the parties refer to it"; the scope of the advisory jurisdiction granted to it pursuant to Article 65, whereby it may address "any legal question at the request of whatever body may be authorized ... to make such a request", and some of the Court's own pronouncements (notably in the Namibia, Lockerbie and Bosnia (Provisional Measures) cases in all of which decisions of the Security Council were discussed), may indicate that the Court would not be precluded from reviewing action taken by an organ of the United Nations in the light of the Charter, provided there were valid jurisdictional grounds for doing so. ${ }^{17}$

It may be expected that a process of democratization should lead to consideration of the composition of the Court itself. Its Statute contains no indication of the "main forms" of civilization or the "principal" legal systems which, by Article 9 are to be "represented" on the Court, nor would it seem feasible for it to have done so. However, if "civilizations" or "legal systems" are related to religious origins, as is frequently the case, it is obvious that important civilizations and legal systems are either not represented or are disproportionately represented in the Court as presently composed.

Thrown back upon the more readily applicable principles of equity and geography as the practical means of giving effect to Article 9, it would seem difficult to maintain that a membership of 15 judges, thought to be adequately 'representative' in 1921 when the League's membership was less than 30, should still be considered adequately representative of a United Nations membership of nearly double that number in 1946, and more than six times that number today. Moreover, if on the International Law Commission a membership of no less than 34 is currently considered necessary for representation of 'civilizations' and 'legal systems', it is difficult to see how a membership of 15 is sufficient for the same purpose on the Court. By contrast,

\footnotetext{
${ }^{16}$ A proposal at the San Francisco Conference to confer on the Court a general power to resolve disputes concerning interpretations of the Charter, could not be adopted. UNCIO Docs. Vol. 3, p. 633.

${ }^{17}$ For a review and analysis of the arguments for and against recognition of a power of judicial review in the International Court of Justice, see LUCIUS CAFLISCH, 'Is the International Court entitled to review Security Council Resolutions adopted under Chapter VII of the United Nations Charter?', paper presented at the Qatar International Law Conference 22-5 March 1994. See also a paper presented at the same Conference by THOMAS M. FRANCK, 'The political and judicial empires: must there be a conflict over conflict-resolution?', and G.R. WATSON, 'Constitutionalism, Judicial Review, and the World Court', in 34 Harvard International Law Journal (1993), 1-46.
} 
the International Tribunal for the Law of the Sea is to be composed of 21 judges, while in at least two regional courts, viz. the European Court of Justice and the European Court of Human Rights, each member state may appoint a judge.

A process of democratization would seem to indicate the desirability of a modest expansion of the Court's membership from 15 perhaps to 23, in order to make it more 'representative' of the UN's expanded membership. Although not an ideal solution, ${ }^{18}$ such a course may be needed inter alia in order to balance the prospective increase in the number of permanent members of the Security Council which will probably mean a corresponding increase in the number of informally 'reserved' seats on the Court, reducing still further the number of places to which the generality of states could be elected. In addition, a new 'gentlemen's agreement' should seek to promote opportunities for all States to have their qualified candidates elected to the Court, and abandonment of practices that restricted those opportunities in the past. Thus, states could agree to show restraint in the matter of successive candidacies of sitting judges, or of candidacies of their other nationals to succeed them; and a state could agree not to 'claim' for one of its nationals the remainder of a term of a judge of its nationality who died in office (a practice that seems inconsistent with the letter and spirit of the Statute), if one of its nationals in the past completed a full nine-year term.

\footnotetext{
${ }^{18}$ There is considerable weight in arguments against such an increase, including that of operational inefficiency. However, it is difficult to avoid the conclusion that such an expansion would help maintain the Court's representational character, since pressure for informal 'reservation' of seats is not likely to diminish. It would, of course, be necessary to convince current and future permanent members of the Security Council of the fairness implicit in expansion.
} 